MariJa TuRK

FILOZOFSKI FAKULTET SVEUČILIŠta U RIJECI

RIJEKA, HRVATSKA

mturk@ffri.hr

Nina SpiciJarić PašKvan

ZAVOd ZA POVIJESNE I DRUŠTVENE ZNANOSTI, HAZU, RIJEKA

RIJEKA, HRVATSKA

nspicijaric@hazu.hr

https://doi.org/10.17234/9789531755139.30

\title{
KONTRASTIVNA RAŠČLAMBA KAO POSTUPAK OTKRIVANJA PODRIJETLA FRAZEMA (NA PRIMJERU FRAZEMA SA ZOONIMSKOM SASTAVNICOM) ${ }^{1}$
}

\begin{abstract}
Hrvatski je jezik bio u višestoljetnom dodiru s drugim jezicima koji su ostavili traga i u njegovoj frazeologiji. Jedan od mogućih postupaka otkrivanja ishodišta frazema jest kontrastiranje jednakoznačnih frazema u više jezika. U ovome se prilogu osobita pozornost posvećuje frazemima sa zoonimskom sastavnicom u hrvatskome jeziku u kontrastu s jednakoznačnim frazemima u njemačkome i talijanskome jeziku jer su ti jezici u prošlosti znatno utjecali na hrvatski. Jedan od pokazatelja moguće reprodukcije frazema iz stranog jezika u hrvatski jest stupanj ekvivalencije i stupanj desemantizacije frazemskih sastavnica u jezicima koji se kontrastiraju.
\end{abstract}

Ključne riječi: kontrastivna analiza, zoonimska sastavnica, frazemi, hrvatski jezik, strani jezik

\section{Uvod}

Frazemi se mogu istraživati s različitih aspekata: sa strukturnog i semantičkog gledišta. Noviji se pristupi bave psiholingvističkim, kognitivnim, komunikativno-pragmatičkim i lingvokulturalnim aspektom frazema pojedinog jezika. Od uspostave frazeologije kao samostalne discipline frazemi se pojedinog jezika proučavaju u odnosu na slične fenomene $u$ drugim jezicima. Jedno od otvorenih pitanja $u$ frazeologiji je pitanje njihova podrijetla. Poznato je, naime, da u svakome jeziku postoje frazemi koji su svojstveni samo tome jeziku i frazemi koji su preuzeti iz drugih jezika. Nacionalni frazemi izriču posebnosti naroda u kojem su nastali, običaje, shvaćanja, nacionalne mitove i sl. Frazemi u najširem smislu ${ }^{2}$ preuzeti iz drugih jezika javljaju se u neprevedenom ili, još češće, u prevedenom obliku i postaju svojinom jezika koji ih je preuzeo. Prevedeni ili kalkirani frazemi na izraznoj razini nemaju tragova stranih jezika i ne osjećaju se stranima

Rad je nastao u okviru projekta „Unutarnje posuđivanje u hrvatskome jeziku“ koji financijski podupire Sveučilište u Rijeci.

2 Pod frazemima u najširem smislu misli se na sve višerječne jedinice prenesena značenja koje se reproduciraju u gotovome obliku, kao što su krilatice, kolokacije, poslovice i uzrečice. 
(Menac 2007: 127). Ako frazemi istovjetna značenja i strukture, te ekvivalentnih leksičkih sastavnica postoje u više jezika, onda to upućuje na zajedničko podrijetlo tih frazema. Često je nepoznato u kojem je jeziku taj frazem nastao, kako se širio u druge jezike, je li nastao izravnim prevođenjem ili posredstvom kojeg drugog jezika.

Potpunu strukturnu, leksemsku i semantičku ekvivalenciju može potvrditi mnoštvo primjera frazema ne samo u slavenskim već i u drugim europskim jezicima (germanskim i romanskim jezicima, kao i u mađarskome).

Frazeme s jednakom ili sličnom strukturom ${ }^{3}$ i istovjetnim značenjem ilustriraju sljedeći primjeri:

hrv. pasji život 'život u oskudici i ponižavanjima'

engl. a dog's life, njem. Hundesleben, franc. vie de chien, tal. vita da cane, rus. собачья жизнь, mađ. kutya élet

hrv. kupiti / kupovati mačka (mačku) $\boldsymbol{u}$ vreći 'kupiti / kupovati što bez provjere'4

engl. to buy a pig (pup)in a poke, njem. die Katze im Sack kaufen, franc. acheter chat en sac, tal. comprare un gatto in sacco, rus. купить кота в мешке, mađ. zsákbamacskát vesz.

Engleski se frazem djelomično razlikuje od istovjetnih frazema u navedenim jezicima tako što koristi leksem svinja ili štene, dok drugi jezici koriste leksem mačka odnosno ma$\check{c} a k$.

Frazemi jednaka značenja i jednake ili slične strukture te s leksičkom ekvivalencijom pripadaju zajedničkim europskim frazemima iako se za većinu njih ne predmnijeva njihovo strano ishodište, odnosno ne prepoznaju se kao prevedenice.

U ovome se radu nastoji kontrastivnom raščlambom frazema iz više jezika koji imaju podudarnu strukturu, ekvivalentni leksemski sastav i jednako značenje utvrditi moguće podrijetlo. Naime, podudarnost među frazemima različitih jezika jedan je od kriterija za utvrđivanje kalkiranja. U hrvatskom jezikoslovlju malo je radova koji se bave tom problematikom ${ }^{5}$. Osim toga, kontrastivnom je analizom u ovome radu obuhvaćeno više jezika nego u prethodno objavljenim radovima.

Građa na kojoj se temelji kontrastivna raščlamba prikupljena je iz leksikografskih izvora: iz općih jednojezičnih rječnika hrvatskoga, latinskoga, njemačkoga, talijanskoga, engleskoga, francuskoga i mađarskoga jezika, te dvojezičnih i višejezičnih rječnika u kojima je hrvatski polazni ili ciljni jezik. Drugi su izvor za popunu građe bili frazeološki jednojezični ili višejezični rječnici. Odabrani su frazemi provjeravani i na mrežnim pretraživačima.

\section{Internacionalna frazeologija - podudarnosti}

Kad je riječ o internacionalnoj frazeologiji, odnosno o zajedničkim europskim frazemima, obično se govori o onim frazemima kojima je poznato podrijetlo. To su fra-

3 Strukturne razlike među frazemima različitih jezika uvjetovane su gramatičkim slaganjem karakterističnim za pojedine jezike.

$4 \quad$ Frazem je prvotno imao kraći oblik nešto kupiti u vreći i odnosio se na činjenicu da se na tržnici nekad prodavala vreća u kojoj je bila mačka, a nudilo se prase, kunić ili slično (Duden 2002: 408).

5 Usp. Jernej (1986, 1992, 1996), Turk (1994), Turk i Opašić (2008). 
zemi antičkog i biblijskog podrijetla i frazemi književne provenijencije (Vidović Bolt 2011: 43-47).

\subsection{Frazemi grčke i rimske mitologije}

Iz grčke i rimske mitologije potječe u mnogim jezicima mnoštvo frazema. Oni su prevedeni najviše iz latinskoga kao jezika izvornika ili jezika posrednika iz grčkoga ili iz drugih posredničkih jezika. U hrvatskome su jeziku posrednički jezici bili staroslavenski, njemački i talijanski jezik. Međutim, od frazema sa zoonimskom sastavnicom registriran je tek jedan:

hrv. trojanski konj - 'lukava, podla prevara'

lat. equis Troianus, engl. the Troyan Horse, njem. Trojanisches Pferd, franc. cheval de Troie, tal. cavallo di Troia, rus. Троянский конь, češ. trojský kůn̆, polj. koń trojański, mađ. Trójai faló

\subsection{Frazemi biblijskog podrijetla}

Biblijske frazeme sa zoonimskom sastavnicom mogu potvrditi sljedeći frazemi:

hrv. zlatno tele - 'novac (zlato, bogatstvo) kao cilj (svrha)'

lat. vitulus aureus, engl. golden calf, njem. das goldene Kalb, franc. le veau d'or, tal. vitello d'oro, rus. золотой телеu, mađ. aranyborjú

hrv. izgubljena (zalutala) ovca - 'osoba koja se odvojila od svoje sredine i pošla pogrešnim životnim putem'

engl. the lost sheep, njem. das verlorene (verirrte) Schaf, franc. brebis égarée, tal. pecora smarrita, rus. заблудшая овиа

hrv. baciti / bacati biserje pred svinje - 'dati / davati (pokazati / pokazivati, pružiti / pružati, reći / govoriti) štogod lijepo onomu koji to ne shvaća (kojega se to ne tiče, koji toga nije vrijedan ili dostojan)'

lat. margaritas ante porcos mittere (iacere) ${ }^{7}$, engl. cast (throw) pearls before swine, njem. Perlen vor die Säue werfen, franc. jetar des perles aux pourceaux (cochons), tal. gettar perle ai porci, rus. метать бисер перед свиньями

\subsection{Frazemi književne provenijencije}

Frazemi književne provenijencije reproducirani su u hrvatski i u druge jezike s potpunom ili djelomičnom ekvivalencijom. Kad se govori o djelomičnoj ekvivalenciji, misli se na činjenicu da se frazemi pojedinih jezika razlikuju samo u jednoj leksičkoj sastavnici, ali ti leksemi pripadaju istome semantičkom polju ili asocijativnom nizu. Pozadinska slika je tek neznatno izmijenjena, a frazemsko je značenje jednako.

6 U mađarskom je doslovno značenje trojanski drveni konj.

7 Frazem je biblijskoga podrijetla jer je nastao prema rečenici iz Matejeva evanđelja: Ne dajte svetinje psima! Ne bacajte svoga biserja pred svinje, da se, pošto ga pogaze, ne okrenu te vas rastrgaju! (Opašić 2013: 197). 


\section{Ezop:}

hrv. jedna lasta ne čini proljeće - 'jedan znak na početku još ne znači da će se što ostvariti u potpunosti'

lat. una hirundo non facit ver, engl. one swallow makes no summer, njem. eine Schwalbe macht noch keinen Sommer (Frühling), franc. une hirondelle ne fait pas le printemps, tal. una rondine non fa primavera, rus. одна ласточка весны не делает, mađ. egy fecske nem csinál nyarat

$\mathrm{U}$ njemačkom frazemu alterniraju proljeće i ljeto, dok u engleskom i mađarskom postoji samo ljeto.

Erazmus:

hrv. riba smrdi od glave - 'nevolje dolaze od pretpostavljenih, kriva je nesposobnost onih koji zapovijedaju ili upravljaju'

lat. piscis primum a capite foetet, engl. the fish rots from the head down, njem. der Fisch stinkt vom Kopfe, franc. le poisson pourrit par la téte, tal. il pesce puzza dal capo (dalla testa), rus. pыба с головы гниет, mađ.fejétöl büzlik a hal

Ove se frazemske jedinice razlikuju po sastavnici asocijativno bliskih glagola: smrdjeti (njem. stinken, tal. puzzare, mađ. büzlik), odnosno trunuti (engl. rot, franc. pourrir, rus. гнить).

hrv. vuk dlaku mijenja, ali ćud nikada - 'ljudi se prilagođavaju prilikama, ali narav ne mijenjaju'

lat. lupus pilum mutat, non mentum, engl. a wolf changes its appearance, but never its nature, njem. der Wolf ändert das Haar und bleibt wie er war, tal. il lupo perde il pelo, ma non il vizio

Ezop i kasnije Ciceron:

hrv. hraniti zmiju (guju) u njedrima - 'biti dobar onomu koji će zlom uzvratiti'

lat. In sinu atque in deliciis viperam illam venenatam ac pestiferam habere ${ }^{8}$, engl. to cherish a serpent in one's bosom, njem. eine Schlange (Natter) am Busen nähren, tal. allevare (nutrire) una serpe in seno, rus. отогреть/отогревать (пригреть) змею на груди (за пазухой), mađ. kígyót melenget a keblén

Mađarski i ruski frazemi se djelomično razlikuju od frazema u ostalim navedenim jezicima tako što koriste glagol grijati, dok drugi jezici koriste hraniti.

Horacije:

hrv. tresla se brda, rodio se miš - 'činilo se da će se dogoditi nešto strašno, a zapravo su posljedice bile male'

lat. Parturient montes, nascetur ridiculus mus ${ }^{9}$, njem. der Berg kreißte und gebar eine Maus, tal. fare come la montagna che partorì il topo

8 Latinski frazem znači 'hraniti onu otrovnu i pogubnu guju na grudima i voljeti je’ (Marević 2002: 247).

9 Horacije se ovime narugao herojskim naporima koji daju slabe rezultate. Njegov je stih također aluzija na jednu Ezopovu basnu, Tresla se brda (Marević 2002: 433). 
Hrvatski, njemački i talijanski frazemi su slični i djelomice odstupaju od latinskog originala.

\section{Juvenal:}

Prema lat. rara avis u hrvatskome su nastala dva frazema: jedan vjerno preslikava latinski model - rijetka ptica, a drugi je slobodni prijevod - bijela vrana. Oba frazema imaju bliska značenja: prvi znači 'neobična osoba, osoba kakva se rijetko susreće', a drugi 'osoba različita od drugih, osoba koja se razlikuje od svoje sredine'.

Latinski je izraz u neprevedenom obliku prenesen u engleski jezik - rara avis. U drugim je jezicima reproduciran u slobodnom prijevodu:

njem. ein weißer Rabe, franc. le merle blanc, tal. mоsca bianca, rus. белая ворона, češ. vzácný pták, bilá vrána, polj. rzadki ptak, biały kruk, mađ. fehér holló.

Kao i u hrvatskome, tako je u češkom i poljskom latinski izraz reproduciran na dva načina: jedan u doslovnom, a drugi u slobodnom prijevodu. Slobodan prijevod jednak je u hrvatskom, ruskom i poljskom jeziku, u njemačkom i mađarskom glasi „bijeli gavran“ dok je u talijanskom i francuskom „bijela muha“. Zajedničko je svim tim frazemima nastalim slobodnim prijevodom to što nosive leksičke sastavnice označavaju nešto što leti, a značenje 'različito, neobično' temelji se na paradoksu jer vrana, gavran i muha nisu bijeli.

\section{Leksemske alternacije u frazemima u pojedinim jezicima}

Prethodni je primjer pokazao da se istoznačni frazemi nastali prema jednom modelu mogu razlikovati u jednoj leksičkoj sastavnici. U skupini općeeuropskih frazema postoji relativno velik broj strukturno i semantički podudarnih frazema koji se razlikuju po nosivoj zoonimskoj sastavnici. Nosive su sastavnice u nekom semantičkom odnosu i podudaraju se bar u jednom semu, često su hiponimi nekog hiperonima. Kao primjere navodimo nekoliko frazema s različitim hiponimima koji pripadaju hiperonimu insekt:

hrv. praviti od (iz) buhe (muhe, komarca) slona - 'pretjerivati $и$ čemu,

preuveličavati što "

lat. Elephantum ex musca facis ${ }^{10}$, njem. aus einer Mücke einen Elefanten machen, franc. faire d'une mouche un éléphant, tal. far di una mosca un elefante, rus. делать из мухи слона, mađ. szúnyogból is elefántot csinál

$\mathrm{U}$ hrvatskome su zoonimske sastavnice buha, muha, komarac, u francuskom, ruskom i talijanskom muha, a u njemačkom i mađarskom komarac.

hrv. imati bube (bubice, muhe, mušice) u glavi - 'zanositi se ludim mislima, čudnim zamislima'

njem. Motten im Kopf haben, tal. avere i grilli per il capo, avere i grilli per la testa, avere la testa piena di grilli, avere il capo pieno di grilli, avere i grilli in testa

$\overline{10}$ Doslovno: Praviš iz muhe slona (Marević 2002: 148). 
U hrvatskome alterira više sastavnica, u njemačkom je sastavnica moljac, a u talijanskom cvrčci (zrikavci).

\section{Kontrastivna analiza i podrijetlo frazema}

U prethodnim smo poglavljima pokazali primjere frazema kojima je poznato podrijetlo. Njihovom usporedbom u različitim jezicima može se utvrditi da se frazemi reproduciraju u hrvatski i u druge jezike doslovno i da su podudarne strukture. Iz pojedinih je primjera vidljivo da se u hrvatskome, kao i u drugim jezicima, uvijek ne prenosi vjerno original i da su odstupanja uvjetovana gramatičkom strukturom pojedinog jezika ili specifičnim izborom jedne leksičke sastavnice. Kontrastivna analiza frazema čije podrijetlo nije poznato može biti jedan od pokazatelja njihova podrijetla. Kako je podudarnost jedan od pokazatelja mogućeg kalkiranja, u ovoj se analizi uzimaju u obzir samo frazemi istoga značenja i potpune ili velike ekvivalencije. Ako je utvrđena podudarnost u više jezika, to sigurno upućuje na to da je riječ o kalkiranju, ali je u većini slučajeva teško utvrditi u kojem je jeziku frazem nastao i kako se širio u druge jezike, je li se širio izravno ili posredstvom jednog ili više drugih jezika. Sljedeći primjeri pokazuju postojanje ekvivalentnih frazema u više europskih jezika, čije podrijetlo i putovi širenja nisu poznati:

hrv. biti (ponašati se) kao slon u staklani (trgovini porculana) ima dva značenja

1. biti jako nespretan, nanositi štetu svojom nespretnošću

2. neadekvatno se ponašati, praviti štetu svojim ponašanjem

engl. behave like a bull in a china shop, njem. sich wie ein Elefant im Porzellanladen benehmen, franc. être comme un éléphant dans un magasin de porcelaine, tal. muoversi come un elefante in una cristalleria, essere un elefante in un negozio di porcellane, rus. вести себя как слон в посудной лавке

Za označavanje velike i nezgrapne životinje svi navedeni jezici koriste slona, dok je u engleskom riječ o biku. Druge razlike u ovome frazemu među jezicima očituju se u alternaciji leksema: trgovina porculana, staklarna i trgovina kristalom. Ovako velika podudarnost među jezicima jasno upućuje na zaključak da se radi o kalkiranju. Međutim, podrijetlo tog frazema nije poznato (Piirainen 2012: 477).

hrv. štakori napuštaju brod koji tone 'kad se sprema velika opasnost (slom, politički preokret itd.) najlukaviji se prvi spašavaju'

engl. rats desert the sinking ship, njem. die Ratten verlassen das sinkende Schiff, franc. les rats quittent (abandonnent) le navire, tal. quando la nave affonda i topi fuggono (sono i primi a fuggire), i topi sono i primi a lasciare la nave che affonda, rus. крысы бегут с тонущего корабля

U ovom se primjeru očito radi o kalkiranju jer frazem u svim jezicima ima jednaku strukturu, istovjetne sastavnice, identičnu semantičku preobrazbu i jednako značenje. Pouzdani podaci o njegovu podrijetlu ne postoje.

Postojanje podudarnosti među frazemima u jezicima koji su bili ili jesu u kontaktu jedan je od pokazatelja mogućeg preuzimanja frazema u prevedenom obliku. Međutim, 
koliko god je podudarnost među jezičnim jedinicama neizostavni i najvažniji indikator kalkiranja, ona sama po sebi nije dovoljan i pouzdan pokazatelj da su pojedini frazemi prevedeni. To se prije svega odnosi na poredbene frazeme koji se temelje na zajedničkom iskustvu govornika različitih jezika. ${ }^{11}$ Pogrešno bi bilo tvrditi da svi ekvivalentni poredbeni frazemi imaju zajedničko ishodište. Podudarni frazemi u više jezika iskustveni su odgovor na ponašanje, izgled, karakteristike pojedinih životinja i stereotipe o njima. Stereotipi se mogu pripisati bilo kojem denotatu, a zbog antropocentričnog uređenja svijeta živim se bićima obično pripisuju ljudske karakteristike. To dolazi do izražaja osobito u odnosu čovjeka prema životinjama (Bertoša 1999: 64). Stereotipi se mogu razlikovati od jezika do jezika, npr.

hrv. dosadan kao stjenica (uš) - 'jako dosadan, nametljiv'

njem. lästig wie eine Fliege, tal. noioso come una mosca, noioso come una piattola, noioso (fastidioso) come una pulce, noioso (fastidioso) come una vespa, noioso come una zanzara, noioso come un calabrone

Ovi se istoznačni frazemi međusobno razlikuju po nosivoj sastavnici karakterističnoj za pojedini jezik. Pojavljuju se leksemi koji označavaju različite kukce koji upornim nadiranjem, obično popraćeno zujanjem iritiraju ljude. U hrvatskom je to stjenica ili uš, u njemačkom muha, a u talijanskom su moguće alternacije: muha, žohar, buha, osa, komarac, stršljen.

Ova je analiza pokazala da je jezična uporaba stereotipa o životinjama uglavnom univerzalna pojava, npr.

hrv. gol (siromašan, ubog) kao crkveni miš - 'jako siromašan'

engl. poor as a church mouse, njem. arm wie eine Kirchenmaus, tal. povero come un topo di chiesa, mađ. szegény, mint a templom egere

Značenje 'siromašan' naglašeno je leksemom crkveni s obzirom na činjenicu da u crkvi ne postoje materijalna sredstva kojim se mogu namirati fiziološke potrebe gladi i žeđi.

Čovjek opisuje životinje stvarajući o njima stereotipe i iskorištava ih da bi obilježio drugog čovjeka. Frazemi u kojima su životinjama pripisane ljudske karakteristike nose procjenu o umnom, osjećajnom i moralnom čovjekovu habitusu, npr.

hrv. crna ovca - 'osoba koja se svojim ponašanjem (stavovima) razlikuje od ostalih (sredine, okruženja), iznimka /ob. u lošem smislu/'

engl. the black sheep, njem. das schwarze Schaf, franc. mouton noir, tal. la pecora nera, mađ. fekete bárány ${ }^{12}$

Značenje se ovog frazema temelji na činjenici da su ovce rijetko crne pa se tako razlikuju od drugih ovaca u stadu.

hrv. biti prava zmija - 'biti zla, opaka osoba'

engl. to be a real snake, njem. eine richtige Schlange sein, franc. être une vraie vipère, tal. essere un vero serpente, rus. быть настоящей змеёŭ, mađ. kigyófajzat ${ }^{13}$

\footnotetext{
11 O značajkama poredbenih frazema vidi Fink-Arsovski (2002).

12 U mađarskom umjesto crne ovce stoji crno janje.

13 Mađ. kigyófajzat doslovno znači zmijska sorta.
} 
hrv. lukav kao lisica - 'izrazito lukav'

engl. sly as a fox, njem. schlau wie ein Fuchs, franc. rusé comme un renard, tal. furbo come una volpe, rus. хитрый как лиса, mađ. ravasz, mint a róka

hrv. hrabar kao lav - 'izrazito hrabar'

engl. lion-hearted, njem. mutig wie ein Löwe, franc. courageux comme un lion, tal. coraggioso come un leone, rus. смельй как лев, mađ. bátor, mint az oroszlán

hrv. radišan kao mrav - 'izrazito marljiv, radišan'

njem. fleißig wie eine Ameise, tal. attivo (laborioso) come una formica, rus. трудолюбивым как муравей, mađ. szorgalmas, mint a hangya

hrv. plašljiv kao zec - 'jako strašljiv'

engl. timid as a rabbit, njem. furchtsam (schreckhaft) wie ein Hase, franc. peureux comme un lièvre, tal. timido (pauroso) come una lepre, rus. трусливый как заяи, mađ. gyáva, mint a nyúl

Neki frazemi oslikavaju vanjštinu, tj. temelje se na iskustvu izgleda, svojstava ili ponašanja životinja, prenose se na čovjeka, ali ne predstavljaju stereotipe s moralnom procjenom, npr.

hrv. crven kao rak - 'vrlo crven u licu, pocrvenio /od sunca, ljutnje itd./'

engl. as red as lobster, njem. rot wie ein Krebs (krebsrot), franc. rouge comme une écrevisse, tal. rosso come un gambero, rus. красный как рак, mađ. vörös, mint a rák

hrv. slijep kao krtica - 'jako slijep'

engl. blind as a mole, njem. blind wie ein Maulwurf, franc. myope comme une taupe, tal. сіесо соте иna talpa, rus. слепой как крот

hrv. spavati kao zec - 'imati lagan san, buditi se na svaki šum'

njem. den Hasenschlaf schlafen, franc. avoir un sommeil de lièvre, tal. dormire come una lepre, rus. спать как заяч

hrv. živjeti kao golubovi (kao dva goluba, kao golub i golubica) - 'živjeti u slozi i ljubavi'

engl. to live like a couple of lovebirds, njem. wie die Turteltauben leben, tal. vivere come due colombini

hrv. živjeti (slagati se) kao pas i mačka - 'živjeti u stalnom neprijateljstvu'

engl. to live like cat and dog, njem. wie Hund und Katze leben, franc. s'entendre comme chien et chat, tal. vivere come cane e gatto, mađ. úgy élnek, mint a kutya meg a macska

Za navedene se primjere ne bi moglo reći da su nastali kalkiranjem bez obzira na činjenicu što su semantički i strukturno podudarni. Oni se temelje na univerzalnim iskustvima pripadnika različitih naroda i njihovih jezika.

Latinski je u frazeologiji hrvatskoga jezika ostavio tragova u neprevedenom obliku, npr. lupus in fabula, ali je njegov utjecaj još veći u prevedenom obliku, a to se, kao što je pokazano, osobito odnosi na frazeme biblijskog, klasičnog i književnog podrijetla. Osim latinskoga na hrvatski su jezik znatno utjecali njemački i talijanski jezik. Kontrastivna raščlamba jednakoznačnih frazema pokazuje znatna podudaranja, na što je još devedesetih godina dvadesetoga stoljeća u nekoliko članaka uputio prof. Josip Jernej (1986, 1992, 1996). U 
kalkiranju osim podudarnosti treba uzeti u obzir veliki stupanj desemantizacije frazemskih sastavnica. Ako su sve sastavnice frazema u dva jezika desemantizirane ili većina njih, onda je malo vjerojatno da su se u dva nesrodna jezika razvili ekvivalentni frazemi.

\subsection{Utjecaj njemačkog jezika na hrvatske frazeme}

Pretpostavka je da su sljedeći frazemi mogli nastati preslikom njemačkih frazema:

hrv. podmetnuti komu kukavičje jaje < njem. jdm. ein Kuckucksei ins Nest legen 'podmetnuti komu što s lošom namjerom'

hrv. vidjeti bijele miševe < njem. weiße Mäuse sehen - 'halucinirati'

hrv. jednim udarcem ubiti dvije muhe $e^{14}<$ njem. zwei Fliege mit einer Klappe schlagen - 'poduzeti što da se ostvari dvostruka korist, istom akcijom postići dva probitka'

hrv. to <već> $i$ vrapci $<$ na krovu $>$ znaju (cvrkuću, pjevaju) < njem. das pfeifen die Spatzen von den <alten $>$ Dächern - 'to je svima poznato'

hrv. kao ptica nebeska < njem. wie die Vögel des Himmels - 'bezbrižno, ravnodušno, nebrineći suviše za sutrašnjicu'

hrv. vidjela žaba gdje konja potkivaju pa i ona digla nogu $<$ njem. wenn der Frosch sieht, wie man das Pferd beschlägt, er gleich seinen Fuß zum Schmiede hält - 'o onome koji slijepo slijedi tuđe postupke kojima nije dorastao ili koji su iznad njegovih mogućnosti'

hrv. knjiški moljac < njem. Bücherwurm - 'onaj koji stalno traži po knjigama, onaj koji je stalno među knjigama'. U ovom je primjeru riječ o djelomičnoj prevedenici jer se radi o odstupanju prijevoda u jednoj sastavnici u odnosu na predložak. Naime, u njemačkoj složenici osnovna je riječ Wurm, tj. crv. Iako i u mađarskom postoji izraz könyvmoly 'knjiški moljac', što je bliže hrvatskome od njemačkog izraza, u prilog mogućnosti da se radi o njemačkom kalku govori činjenica da se u hrvatskom rabila posuđenica bihervurm kako je bilježi Klaićev Rječnik stranih riječi.

Njemački je imao i posredničku ulogu u kalkiranju frazema te je u tom slučaju hrvatski frazem podudaran $\mathrm{s}$ njemačkim, a ne s latinskim:

hrv. bolje vrabac u ruci nego golub na grani $(k r o v u)<$ njem. lieber den Spatzen in der Hand als die Taube auf dem Dach < lat. capta avis est melior quam mille in gramine ruris $^{15}$

hrv. pasti s konja na magarca < njem. vom Pferde auf den Essel kommen < lat. Canterio vectum post mulum conscendere ${ }^{16}$

$\overline{14}$ Zanimljivo je kako se jednako značenje izražava u drugim jezicima: engl. kill two birds with one sto$n e$ (dosl. ubiti dvije ptice jednim kamenom), tal. prendere (pigliare) due piccioni (colombi) con una fava (dosl. uhvatiti dva goluba jednim bobom), rus. одним ударом двух зайцев убить (dosl. jednim udarcem ubiti dva zeca).

15 Hrvatski bi doslovni prijevod latinskog frazema glasio: uhvaćena ptica bolja je nego tisuću njih na polju u travi (Marević 2002: 76).

16 Latinski frazem doslovno znači: Jahati najprije na konju, pa onda uzjahati mulu. U latinskom postoji i $a b$ asinis ad boves transcendere 'doći u bolji položaj’, koji doslovno znači: prijeći od magarca na volove. 


\subsection{Utjecaj talijanskoga jezika na hrvatske frazeme}

Sljedeći frazemi potvrđuju pretpostavku o talijanskom uzoru u kalkiranju:

hrv. morski vuk < tal. lupo di mare - 'iskusni pomorac'

hrv. crv sumnje < tal. il tarlo del sospetto - 'dvojba, nelagoda'

hrv. biti kao lav u kavezu < tal. essere un leone in gabbia - 'biti nemiran (nervozan)'

hrv. kao muha bez glave [motati se, juriti i sl.] < tal. come una mosca senza testa (capo) [gironzolare] - 'smeteno, smušeno, nepromišljeno, bez plana [motati se, juriti i sl.]' žaju'.

hrv. biti na konju < tal. essere a cavallo - 'poslije teškoća naći se u boljem polo-

Posrednička uloga talijanskoga vidljiva je u frazemu:

hrv. velike ribe proždiru male ${ }^{17}<$ tal. i pesci grossi mangiano i piccini (quelli piccoli) $<$ lat. pisces minutos magnus comest.

\subsection{Hrvatski frazemi podudarni s frazemima u slavenskim jezicima}

U prikupljenoj građi zabilježeno je nekoliko hrvatskih frazema sa zoonimskom sastavnicom za koje nisu pronađeni paralelizmi u rječnicima germanskih i romanskih jezika, ali su potvrde pronađene u pojedinim slavenskim jezicima (Fink Arsovski i dr. 2006). Ti se frazemi mogu svrstati u skupnu slavenskih frazema. Oni imaju zajedničko ishodište i međusobno neovisan razvoj, tj. malo je vjerojatno da su kalkirani.

ima (bilo je) koga kao mrava (mravi) - 'ima (bilo je) koga vrlo mnogo'

mak. има некого како мравки, bug. има някого като мравки, ukr. $\epsilon$ кого як мурашви, rus. как муравьёв когоk, polj.jest kogoś jak mrówek, češ. je někoho <tam> jako mravennců, slovač. je koho ako mravcov

ljut (srdit) kao ris - 'jako ljutit', bijesan

slov. besen (jezen) kot ris, mak. бесен (лут) како рис, bug. зъл като рис,

marljiv kao krtica - 'vrlo marljiv', mak. вреден (равотлив) како кртица, bug. работлив(работен, трудолюбив) като къртица

\subsection{Nacionalni frazemi}

Kad se govori o nacionalnim frazemima, obično se ističe da su nastali kao iskustveni odgovor na domaće prilike, da su motivirani običajima, vjerovanjima i svjetonazorom naroda u čijem su jeziku nastali. Raščlamba frazema sa zoonimskom sastavnicom pokazuje, međutim, da u srodnim i nesrodnim jezicima ima mnogo sličnosti. Naime, ti se frazemi temelje na univerzalnim iskustvima o izgledu i ponašanju životinja i na stereotipima o njima kojima se obično pripisuju ljudske karakteristike. To objašnjava činjenicu da je broj tipično hrvatskih frazema sa zoonimskom sastavnicom znatno manji od očekivanog, npr.

17 Postoje i inačice: Magnus piscis minutos comest 'velika riba ždere male', Pisces magni parvulos comedunt 'velike ribe proždiru male' (Marević 2002: 305, 456). 
i mi konja za trku imamo - 'i mi imamo čime da se usporedimo'

izjeo (pojeo) vuk magarca (magare) - 'prošlo je bez ikakvih posljedica, zataškana je neugodna stvar'

izvoditi bijesne gliste - 'izmotavati se, prenemagati se'

kao da je zmija (guja) ujela koga [skočiti, vrisnuti itd.] - 'naglo, brzo; teško, bolno povrijeđen (uvrijeđen, razočaran) [skočiti, vrisnuti itd.]'

kolju se kao žuti mravi - 'bore se nepomirljivo, do uništenja'

ne bi $<$ ni> mrava zgazio - 'ne bi mogao učiniti nikome ni najmanje zlo'

rugala se sova sjenici - 'prigovarati, rugati se komu za karakteristike koje ima i sâm onaj koji se ruga'

spremiti ražanj, a zec и šumi ${ }^{18}$ - 'spremati se za što nesigurno, preuraniti s veseljem, veseliti se onome što je još daleko od ostvarenja'

tjerati lisicu, istjerati vuka - 'boriti se protiv jednog neprijatelja, a naići na još goreg; misleći da se bori protiv slabog otkriti jakog'

u tom grmu leži zec ${ }^{19}$ - 'u tome je stvar, u tome je problem'

vrana je komu mozak (pamet) popila - 'ne zna što radi tko'

znam te ptico dok si jaje bila - 'znam te odmalena'

$<\boldsymbol{i}>$ vuk sit i koza cijela - 'svima je po volji, svi su zadovoljni', usp. rus. волки cblmbl, и овиьы целль, polj. $i$ wilk syty i koza cała

\section{Zaključak}

U analiziranoj građi postoji mnoštvo frazema sa zoonimskom sastavnicom koji su zajednički hrvatskome i drugim slavenskim i neslavenskim jezicima, osobito njemačkome i talijanskome jeziku. Kontrastivna analiza prvi je korak u otkrivanju podrijetla frazema, ali je bez dodatnih istraživanja nemoguće sa sigurnošću govoriti o pravome podrijetlu: jesu li pojedini frazemi kalkirani ili ne, ako su kalkirani iz kojeg su jezika preuzeti, jesu li preuzeti izravno ili posredstvom drugog jezika. Ako su ekvivalentni frazemi potvrđeni u jezicima koji su bili u bliskom kontaktu i imaju veliki odmak od osnovnog značenja njihovih sastavnica, tj. visok stupanj desemantizacije, onda je to jedan od pokazatelja moguće reprodukcije frazema iz jednog jezika u drugi jer je malo vjerojatno da bi se u dva nesrodna jezika razvili ekvivalentni frazemi s velikom semantičkom preoblikom njihovih sastavnica.

$18 \quad$ Usp. lat. Currens per prata non est lepus esca parata, dosl. zec koji bježi po livadi nije još gotova pečenka (Marević 2002: 111).

19 U latinskom postoji sličan frazem: Hic iacet lepus, doslovno: tu leži zec (Marević 2002: 207). 


\section{LITERATURA}

Bertoša, Mislava. 1999. Stereotipi o životinjama. U: Teorija i mogućnosti primjene pragmalingvistike. Badurina, Lada; Ivanetić, Nada; Pritchard, Boris; Stolac, Dijana (red.). Rijeka - Zagreb: Hrvatsko društvo za primijenjenu lingvistiku. 63-76.

Bunk, Ana; Opašić, Maja. 2010. Prilog kontrastivnoj analizi frazema sa zoonimskom sastavnicom u hrvatskome i češkome jeziku. Rasprave Instituta za hrvatski jezik i jezikoslovlje. 32/2: 327-250.

Fink-Arsovski, Željka. 2002. Poredbena frazeologija: pogled izvana i iznutra. Zagreb: FF press.

Jernej, Josip. 1987. Fraseologia in chiave contrastiva. Studia Romanica et Anglica Zagrabiensia. XXIII. 1-2: 349-362.

Jernej, Josip. 1992-1993. O klasifikaciji frazema. Filologija. 20-21: 191-197.

Jernej, Josip. 1996. Bilješke oko porijekla naše frazeologije. Suvremena lingvistika. 1-2: 265269.

Ljubičić, Maslina. 1994. O hrvatskim zoonimima: konotativno značenje i frazeologija. Filologija. 22-23: 245-252.

Menac, Antica. 2007. Hrvatska frazeologija. Zagreb: Knjigra.

Opašić, Maja. 2013. Biblizmi u hrvatskome jeziku. Doktorska disertacija. Filozofski fakultet. Sveučilište u Zagrebu. Zagreb.

Turk, Marija. 1994. Naznake o podrijetlu frazema. Fluminensia. 1-2: 37-47.

Turk, Marija; Opašić, Maja. 2008. Supostavna raščlamba frazema. Fluminensia. 1: 323-333.

Vidović Bolt, Ivana. 2011. Životinjski svijet u hrvatskoj i poljskoj frazeologiji I. Zagreb: Hrvatska sveučilišna naklada.

Zovko, Ivana. 2006. Contrastive analysis of English and Croatian phraseology of animals and plants. Riječ. 2: 106-117.

\section{RJEČNICI}

Anić, Vladimir. 2004. Veliki rječnik hrvatskoga jezika. Zagreb: Novi Liber.

Anić, Vladimir et al. 2003. Hrvatski enciklopedijski rječnik. Zagreb: Novi Liber.

Bujas, Željko. 1999. Veliki hrvatsko-engleski rječnik. Zagreb: Nakladni zavod Globus.

Dautović, Matija. 2002. Hrvatsko-ruski rječnik. Zagreb: Školska knjiga.

Dayre, Jean et al. 1996. Hrvatsko-francuski rječnik. Zagreb: Dominović.

Deanović, Mirko; Jernej, Josip. 1984. Talijansko-hrvatski ili srpski rječnik. Zagreb: Školska knjiga.

Deanović, Mirko; Jernej, Josip. 1994. Hrvatsko-talijanski rječnik. Zagreb: Školska knjiga.

Hansen Kokoruš, Renate et al. 2005. Deutsch-kroatisches Universalwörterbuch. Zagreb: Nakladni zavod Globus - Institut za hrvatski jezik i jezikoslovlje. 
Dudenredaktion (red.). 2002. Duden. Redewendungen: Wörterbuch der deutschen Idiomatik. U: Duden in 12 Bänden 2., neubearbeitete und aktualisierte Auflage. Band 11. Mannheim - Leipzig - Wien - Zürich: Dudenverlag.

English-Croatian dictionary. 2004. Filipović, Rudolf (red.). Zagreb: Školska knjiga.

Fink Arsovski, Željka et al. 2006. Hrvatsko-slavenski rječnik poredbenih frazema. Zagreb: Knjigra.

Klaić, Bratoljub. 2007. Rječnik stranih riječi. Zagreb: Školska knjiga.

Korać, Tatjana; Menac, Antica et al. 1979-1980. Русско хорватский или сербский фразеологический словарь / Rusko hrvatski ili srpski frazeološki rječnik. Menac, Antica (red.). sv. I-II. Zagreb: Školska knjiga. [RHSR]

Lapucci, Carlo. 1969. Dizionario dei modi di dire della lingua italiana. Firenze: Valmartina.

Lapucci Carlo. 2006. Dizionario dei provverbi italiani. Firenze: Felice Le Monnier.

Marević, Jozo. 2002. Latinski zauvijek (Latinum in aeternum). Velika Gorica: Marka.

Matešić, Josip et al. 1988. Hrvatsko-njemački frazeološki rječnik. Zagreb: Nakladni zavod Matice hrvatske - München: Verlag Otto Sagner.

Menac, Antica; Vučetić, Zorica. 1995. Hrvatsko-talijanski frazeološki rječnik. Zagreb: Zavod za lingvistiku Filozofskog fakulteta Sveučilišta u Zagrebu.

Menac, Antica; Fink-Arsovski, Željka; Venturin, Radomir. 2003. Hrvatski frazeološki rječnik. Zagreb: Naklada Ljevak.

Osmojezični enciklopedijski rječnik. 1987-2010. Ladan, Tomislav (red.). Zagreb: Leksikografski zavod Miroslav Krleža.

Piirainen, Elisabeth. 2012. Widespread Idiom sin Europe and Beyond. Toward a Lexicon of Common Figurative Units. NewYork, Washington, D/C./Baltimore, Bern, Frankfurt, Berlin, Brussels, Wiena, Oxford: PeterLang.

Pittano, Giuseppe. 1992. Frase fatta capo ha. Bologna: Zanichelli.

Putanec, Valentin. 1989. Dictionnaire français croate ou serbe. Zagreb: Školska knjiga.

Rječnik hrvatskoga jezika. 2000. Šonje, Jure (red.). Zagreb: Leksikografski zavod Miroslav Krleža - Školska knjiga.

Zingarelli, Nicola. 2008. Vocabolario della lingua italiana. Bologna: Zanichelli. 


\section{ZUSAMMENFASSUNG}

\section{KONTRASTIVE ANALYSE ALS METHODE ZUR AUFDECKUNG DER HERKUNFT VON PHRASEMEN (AM BEISPIEL DER PHRASEME MIT ZOONYMISCHER KOMPONENTE)}

Die kroatische Sprache stand in einem jahrhundertelangen Kontakt mit anderen Sprachen. Durch diesen Kontakt wurde auch der Bereich der kroatischen Phraseologie bedeutsam beeinflusst. Als eine der möglichen Methoden zur Aufdeckung der Herkunft von Phrasemen kann die Gegenüberstellung von gleichbedeutenden Phrasemen mehrerer kontaktierender Sprachen angesehen werden. Im Mittelpunkt des Interesses stehen in diesem Beitrag kroatische Phraseme mit zoonymischer Komponente und die ihnen gegenübergestellten gleichbedeutenden Phraseme des Deutschen und des Italienischen, da die beiden letztgenannten Sprachen in der Vergangenheit einen bemerkenswert großen Einfluss auf die kroatische Sprache ausgeübt haben. Als Indikatoren für die mögliche Reproduktion der Phraseme aus einer Fremdsprache in die kroatische Sprache können der Äquivalenzgrad und der Grad der Desemantisierung der Phrasemkomponenten der miteinander in Kontakt tretenden Sprachen angesehen werden.

Schlüsselwörter: kontrastive Analyse, zoonymische Komponente, Phrasem, die kroatische Sprache, Fremdsprache 